\title{
目視検査の判断ミスとその機構 ${ }^{*}$
}

\section{伊藤郁男**}

So-called Type 1 and 2 errors were discussed with the one channel entropy model which was introduced by the assumption that the inspectator will judge on criterion to minimize the cost expected by miss-judgments. The discrepancies of actual data from the entropy model were computed, and it was found these discrepancies varied widely by the cost ratio of good's manufacturing and recovering of rejectives.

The fact was also found that reactions were introduced naturally to move the criterion point to make even the results when the same kind of result of judgment had continued.

感覚にたよる検查に拈いて，良品を不合格とする誤りやその逆の誤りについて定量的に研究し，これを 検査ミスによる損失の最小を目標とする1因子エントロピモデルにあてはめて論じた. そしてこのモデル からのかい離度は, 製品コストと不良品が市場へ出まわったときの不信用に関するコストとの比によって 大幅に違うことが示された。 また提示される視標の数に対し合格（または不合格）の視標が多く続けば， 判定の基準を主観的に修正し，結果を平滑化しょうとする反作用現象が発生することを定量的に導いた.

\section{1. まえがき}

感覚に頼る品質検査に際して, 合否の判定を明快に下 せる場合は稀で, たいていは連続した内容の, ある点で 線引をしなければならない.てのとき，たとえば目視検 查において目の錯覚は別として, 心理的要因による判断 の誤りが不可避的に生じる. ての誤りのなかには，良品 を不合格とする誤り（第 1 種の詋りと呼ぶ）と，不良品 を合格とする誤り（第 2 種の䛊り）とが存在するが, 前 者は製品コストにかかわる損失を, 後者は市場での信頼 に対する損失を生む.

そてで上司は，検査員に 1 個あたりの製造コストと不 良品の回収コストとを事前に十分説明し, 検査ミスによ る損害を最小にするよう注意を与えるであろうが，検査 員はその注意に忠実に従うとしても, 結局は精神の緊張 のもとでの勘に頼る以外にない.しかしての勘は緊張と 弛緩により，また心理的外因によって変動する．乙れが 検査結果にとにどの上うに影響するかを知るため，筆者

* 昭和 56 年 3 月 20 日受付

** 関西大学 工学部

Faculty of Engineering, Kansai Univ.
は目視検查にどのように影響するかを知るため，筆者は 目視検査における誤り発生のメカニズムに，検査ミスに よる損失のみに注目した ${ }^{2)} 1$ 因子エントロピモデルを当 てはめ, 検査の難易度との関係をみた。

\section{2. エントロピモデル}

検查員が被検物を前にして合否を判定するとき，何ら の予備知識もなければ純粋に客観的になりえようが，そ の製造コスト $\left(C_{A}\right)$ と, クレームの回収コスト $\left(C_{B}\right)$ とを知らされていれば，乙れにより何らかの主観が構成 されるであろう．そして，もしミスによる損失が検査員 個人の責任に転嫁されるようなら，主観の構築はさらに 強固になるであろう。 そこで $C_{A}$ 対 $C_{B}$ の比が検查作業 に潜在的に影響するだろうと考えられる.

いま一目みて合否の明らかな視標は正解の確率が高い から，こてで問題とするのは判定の困難な境界線に近い 視標についてである.すなわち検査ミスをおかすととを 前提としたとき，そのミスが第 1 種の詋りか第 2 種の誤 りかについて考察するてとにする.

そてで,つぎの仮定を設ける.

仮定 1 検查員は自己の検査ミスによって生じる損害 
を最小にするべく努力する.

仮定 2 しかし他方において，てのような努力は精神 の緊張を強いるので, 検査員は無意識にての緊 張から逃れようとする.

上記 2 つの仮定が同時に作用するわけであるが，具体 的には場合に応し， 1 が強くでたり，2が強くなったり するであろう。

いま検查、スをおかす確率を $p$ ， 、スをおかさない確 率を $q, p$ の中で第 1 種および第 2 種の誤りをおかす確 率を，それぞれ $p_{A}$ および $p_{B}$ とすれば,

$$
\begin{gathered}
p+q=1 \\
p_{A}+p_{B}=1
\end{gathered}
$$

いま $l, H$ を

$$
\begin{aligned}
& l=\left(C_{A} p_{A}+C_{B} p_{B}\right) \cdot p \\
& H=-p_{A} \log _{2} p_{A}-p_{B} \log _{2} p_{B}
\end{aligned}
$$

と定義すれば，lは仮定 1 で述べた検查ミスによる損害 の期待值を， $H$ は仮定 2 と関連する検查ミスの内容に関 するあいまいさを表している゙3. 検查員がもし緊張から 逃れきるため, 完全に主観を放棄し純中立の立場にもど れば, $p_{A}$ と $p_{B}$ の值は同一となり，乙のとき $H$ は最大と なる ${ }^{3)}$. 仮定 1 と 2 にって，検査員は自然に $l$ を最小 に，Hを最大にしょうとするから, 結局は(2)式の条件の 下で $H / l$ を最大にしようとするととになる，そこでラグ ランジュの乗係数入在導入して， $p_{A}\left(\right.$ または $\left.p_{B}\right)$ は，

$$
\left.\begin{array}{l}
\frac{\partial}{\partial p_{A}}\left[H / l+\lambda\left(p_{A}+p_{B}-1\right)\right]=0 \\
\frac{\partial}{\partial p_{B}}\left[H / l+\lambda\left(p_{A}+p_{B}-1\right)\right]=0
\end{array}\right\}
$$

を満足する值に落ちつくであろう。(5)を解いて,

$$
p_{A}=2^{-C_{A} H p / l}, p_{B}=2^{-C_{B} H p / l}
$$

をうる.とてで $W=2^{H p / l}$ とおけば，(2)と(6)とから

$$
W^{-C A}+W^{-C_{B}}=1
$$

となる. (7)の根は正根がただ 1 つ存在することが確かめ られている4から，てれを $W_{0}$ とすれば，結局仮定 1 ， 2 亿基づく $p_{A}, p_{B}$ は，乙扎海印をつけて，

$$
p_{A} *=W_{0}^{-C_{A}}, p_{B}{ }^{*}=W_{0}^{-C_{B}}
$$

によって与えられる.

\section{3. 判別関数による評価}

仮定 $1 ， 2$ の結果として (8)式がえられた。とてろが実 際の検查では上記仮定以外にさらに複雑な心理的要因が 絡み合って作用するであろう。

たとえば提示される視標の分布幅 $\Delta \theta_{R}$ に比べて，合 格とする許容幅 $\Delta \theta_{S}$ が広く，たいていの視標が合格す る場合は，查定を厳しくして合格率を減らそうとし，逆
に $\Delta \theta_{S}$ が狭い場合は，判定を甘くするような反作用， すなわち平滑化の作用が働くかも知れない，乙の真疑は 別として，もしてのような作用が生じれば， $p_{A}, p_{B}$ の 值はそれぞれ $p_{A}^{*}, p_{B}{ }^{*}$ からずれるであろう.てのズレ の程度を測るため，カルバック (Kullback) の判別関数 $D$ を利用してみる。

$$
\text { すなわち }
$$

$$
D\left(p_{i}, p_{i}^{*}\right)=\sum_{i=A, B} p_{i} \log _{2}\left(p_{i} / p_{i}{ }^{*}\right)
$$

すると，Dはつねに

$$
D\left(p_{i}, p_{i}^{*}\right) \geqq 0
$$

が数学的に証明されている ${ }^{4,5)}$. こてで等号は $p_{i}=p_{i} *$ の ときのみである. Dは 1 つの試行の結果生じる事象に対 し 2 種類の確率分布が想定されるとき, 両分布のかい離 度を測るためのもっとも合理的な関数として広く用いら れているそとしてDはエントロピの拡張されたものであ り,もし $p_{A}^{*}=p_{B} *=1 / 2$ ならば, $D\left(p_{i}, 1 / 2\right)=\log _{2} 2-H$ $=1-H$ と導ける. 乙れは一様分布, すなわちあいまい さが最大の状態からのかい離度を表している。

\section{4. 実験とその手順}

目視検査にかわる実験として, 図 1 亿示すような $\mathrm{V}$ 印 のスライドをスクリーン上に映し，その狭角 $\theta$ の合否を 提示時間 $\tau$ 以内に被験者（男子大学生 10 人）に判定させ る.

視標の作成に際し, 視標の中央值（称呼寸法に相当） $\theta_{N}$ や $\theta$ の分布と分布幅 $\Delta \theta_{R}$,および隣接 $\theta$ 間の間隔 $\Delta \theta$ や合格と認められるべき許容幅 $\Delta \theta_{S}$ 等を決定しなければ ならない。そこで本実験に先だち， $\theta$ の弁別闘を知るた

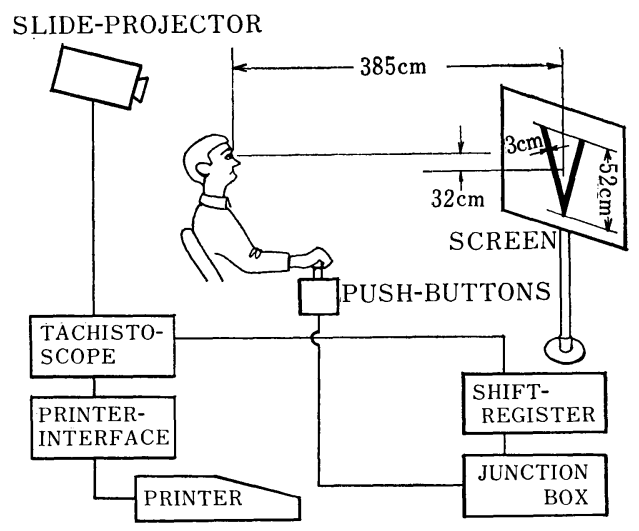

図 1 実験装置の概略図

Fig. 1 Schematic drawing of experimental apparatus. 
表 1 視標スライドの組み合せ要素

Tab. 1 Main elements of composition on slides.

\begin{tabular}{|c|c|c|c|c|c|c|}
\hline$\theta_{N}$ & \multicolumn{2}{|c|}{$30^{\circ}$} & \multicolumn{2}{|c|}{$60^{\circ}$} & \multirow{3}{*}{ 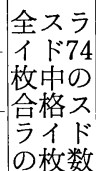 } & \\
\hline$\theta_{R}$ & \multicolumn{2}{|c|}{$20^{\circ} \sim 40^{\circ}$} & \multicolumn{2}{|c|}{$45^{\circ} \sim 70^{\circ}$} & & る理論上 \\
\hline$\Delta \theta_{R}$ & \multicolumn{2}{|c|}{$20^{\circ}$} & \multicolumn{2}{|c|}{$30^{\circ}$} & & の合格率 \\
\hline \multirow[b]{2}{*}{ 合 } & $\theta_{S}$ & $\Delta \theta_{S}$ & $\theta_{S}$ & $\Delta \theta_{S}$ & $n$ & $n / 74$ \\
\hline & $29^{\circ} \sim 31^{\circ}$ & \multicolumn{2}{|c|}{$2^{\circ} 59^{\circ} \sim 61^{\circ} \mid$} & $2^{\circ}$ & 8 & 0.108 \\
\hline 格 & $28^{\circ} \sim 32^{\circ}$ & \multicolumn{2}{|c|}{$4^{\circ} 57^{\circ} \sim 63^{\circ}$} & $6^{\circ}$ & 24 & 0.324 \\
\hline \multirow{2}{*}{ 囲 } & $26^{\circ} \sim 34^{\circ}$ & \multicolumn{2}{|c|}{$8^{\circ} 54^{\circ} \sim 66^{\circ}$} & $12^{\circ}$ & 39 & 0.527 \\
\hline & $22^{\circ} \sim 38^{\circ}$ & 16 & $48^{\circ} \sim 72^{\circ}$ & $24^{\circ}$ & 64 & 0.865 \\
\hline
\end{tabular}

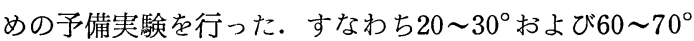
をそれぞれ $1^{\circ}$ 間隔に刻んでカード群を作成し，それらか らランダムに2 枚を選んで同時に提示し，両者間の弁別 を行わせた。 その結果を図 2 に示す。図の横軸は， 2 枚 のカード間の角度の差 $\left(\delta \theta=\theta_{i}-\theta_{j}\right)$ を示している. 図か ら $\delta \theta=4^{\circ}\left(20 \sim 30^{\circ}\right.$ の場合) および $6^{\circ}\left(60 \sim 70^{\circ}\right.$ の場合) でそれぞれ $100 \%$ 弁別できるから，本番用のスライドに は $\Delta \theta$ はこれらの半分, すなわち $2^{\circ}$ および $3^{\circ}$ と定める ととにした. とてで本題からそれるが, 図 2 で, $\delta \theta=1^{\circ}$ のときがもっとも正答率が小さく， $\delta \theta=0$ すなわち，同 角度のカード 2 枚を提示したときの正答率より下まわっ ている，てれから人間は，同じものを「同じ」と認識す る方が，微小な差異を識別するより容易であると考えら れる.

さて本番のスライドにもどり， $\theta$ の分布（角度 $\theta$ のス ライドの出現率) は, 工場での品質検査にてらして, $\theta_{N}$
を中心值とする正規分布を仮定するのが無難と考えられ る. そこで $\theta_{N}=30^{\circ}$ ，標準偏差 $\sigma=10^{\circ}$ のもの，および $\theta_{N}=60^{\circ}, \sigma=15^{\circ}$ の 2 種の $N$-分布スライド群をそれぞ れ74枚作成した. スライドの分布幅 $\Delta \theta_{R}\left(=\theta_{\mathrm{Max}}-\theta_{\mathrm{Min}}\right)$ を表 1 のように選んだとき, 各スライドの角度 $\theta_{i}(i=$ $1,2,3, \cdots, 11)$ に割り当てたスライド枚数 $N_{i}\left(\sum_{i=1}^{11} N_{i}=\right.$ 74）は，上記の正規分布になるよう定められている（両 群とも共通に，順に $5,6,7,7,8,8,8,7,7,6,5$ 枚).

さて，この74枚 1 組のスライド群を提示するに際し， あらかじめ合格とすべき幅（許容幅 $\Delta \theta_{S}$ ）を表 1 のよう に4 水準に定め, 被験者は各水準でとに事前に $\theta_{N}$ と $\Delta \theta_{S}$ の值を教えられたのち，ランダムに提示される $\theta$ に 対し合否を判定する. 表 1 以外の本実験で用いられた変 量と水準は, i ) 提示時間 $\tau=2,5$ 秒, ii ) 価值の比 $C_{A}$ $/ C_{B}=1 / 5,1 / 1,5 / 1$ であった. したがって，てれらの 水準の組み合せによる実験の種類は $2\left(\theta_{N}\right) \times 4\left(\Delta \theta_{S}\right) \times$ $2(\tau) \times 3\left(C_{A} / C_{B}\right)=48$ であり, 実験はそれぞれにつき 10回，したがって総数 480 回行っている.つぎに被験者 に対する実験手順は,

1）上記各水準ごとに， $\theta_{S}$ の両端となるスライドを 10 秒間ずつ交互に 3 回被験者にみせる. 1 種類の実験は 74枚のスライド提示で成り立っているが, データを整理 したところ正 (誤) 答の分布は時間の経過によっては影 響を受けず，被験者の記憶のズレは認められなかった。

2) 乙のとき同時に, $C_{A}, C_{B}$ の值も被験者に徹底さ せる.

3）前記 480 回の実験はランダムな順序に行ったが, さらに前の影響が被験者に残らないよう, 各実験間には
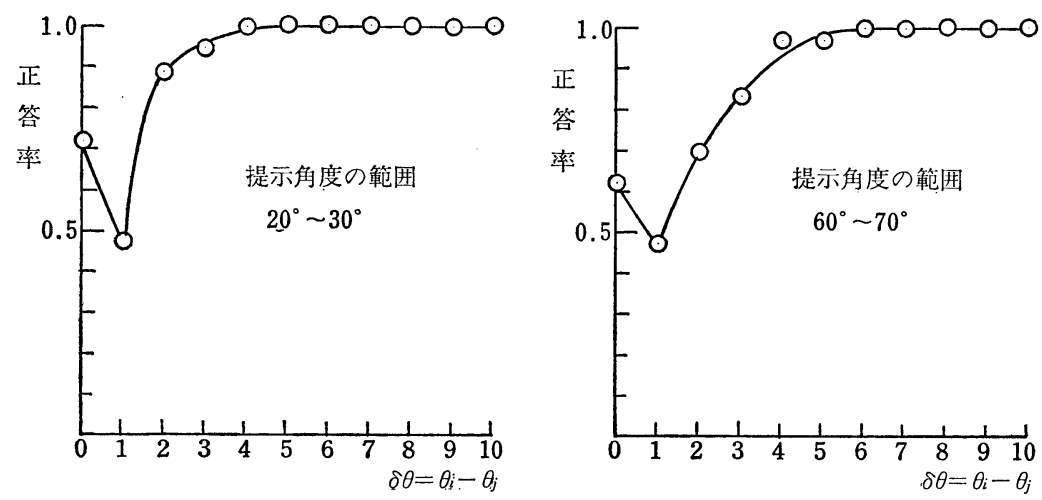

図 2 角度 $\theta$ の弁別闌を求めるための予備実験

Fig. 2 Preliminarly study for knowing a discrimination threshold. 
十分な休㮩を与えてある。

4）実験装置の概略を図 1 亿示す．被験者は左右の手 にそれぞれ押しボタンを持ち, 合否の判断に応じて両者 を押し分ける. 提示時間 $(\tau)$ 内に応答すれば，スライド の電子シャッターが働いて直ちにコマ送りがされる，て がきても応答がなければ未応答と印字してコマ送りが行 われる. これらは短時間で次々と続行されるので, 判断 ごとの正誤については被験者は教えられていない。

\section{5. 実験結果}

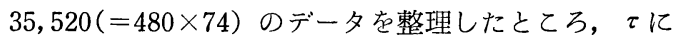
ついては有意な差はほとんど認められなかった。これは 提示時間の 5 秒が長すぎ，ほとんどの被験者が 2 秒以内 に返答し終った結果であり，問題を複雑にするか， $\tau$ を 短くするかの改善が必要である，そてで本報では，てに

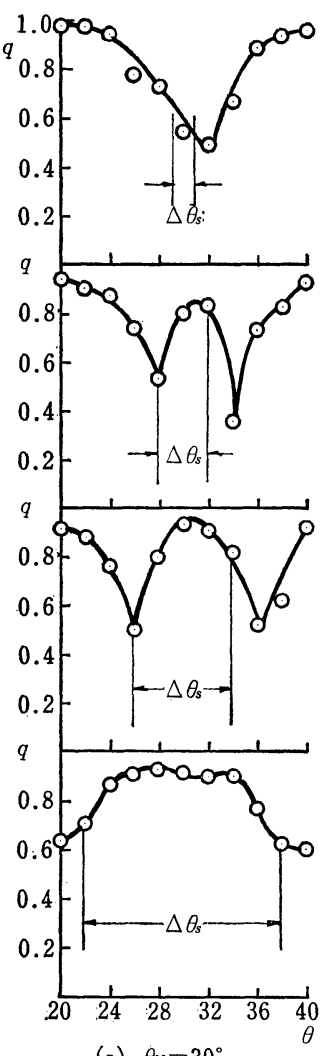

(a) $\theta_{N}=30^{\circ}$

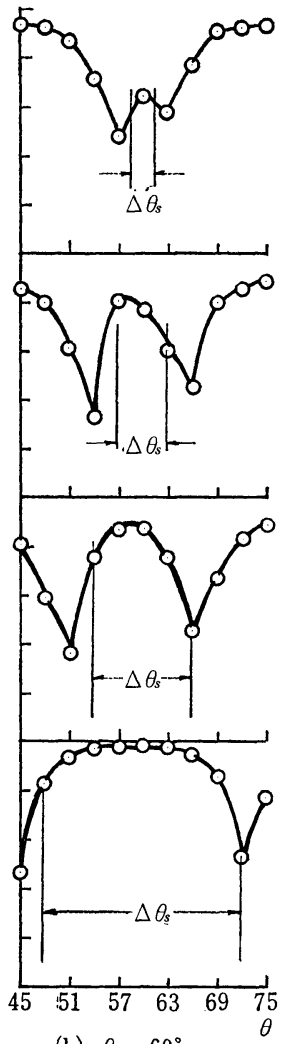

(b) $\theta_{N}=60^{\circ}$
図 3 合格幅 $\Delta \theta \mathrm{s}$ をパラメータとして, 提示角度 $\theta$ に 対する正答率 $q$ の変化

Fig. 3 Probability of correct response $(q)$ with respect to each stimulus $(\theta)$ at a parameter $\Delta \theta_{\mathrm{S}}$.
表 2 この実験の構造

Tab. 2 Composition of this experimental research.

\begin{tabular}{|c|c|c|c|}
\hline \multicolumn{2}{|c|}{ 提 示 判 断 } & 合 & 不 合 \\
\hline 良 & 品 & Hit & 第 1 種の誤り \\
\hline 不 & 良 & 第 2 種の愦り & Correct Rejection \\
\hline
\end{tabular}

関する 2 水準のデータは 1 つにまとめて取り扱う.

さて，乙の実験は表 2 のような構造をもつが，本報で は誤答内での第 1 種および第 2 種の誤りに関する解析を 主たる内容としている，そこで Hit と Correct rejection については，それらを分けずにその生起確率をまとめて $q$ とする. 図 3 (a)，(b)はそれぞれ $\theta_{N}$ が $30^{\circ}$ および $60^{\circ}$ の ときの正答率 $q$ を $\Delta \theta S$ 別に示したものである. $q$ の值は 合格幅 $\theta \Delta_{S}$ の境界上またはそのすぐ外側で急激に落ち 込んでいる.そして $\Delta \theta S$ が狭まるにつれ，落ち込みの 溝をもったままで $\theta$ の中央部付近全体の $q$ が低下してゆ く.すなわち，良品を不合格と判定する誤り（第 1 種の 誤り）が増加するようすを示している.

つぎ図 4 (a)，(b)は，いずれも第 1,2 種の誤り $p_{1}=p$. $p_{A}, p_{2}=p \cdot p_{B}$ の発生のようすを刺激 $\theta$ について例示し たものである. 合否の境界線, すなわち $\phi=\left(\theta-\theta_{N}\right) /$ $\Delta \theta_{S} / 2$ の值が士 1 亿なる点の付近で急峻な山ができてい る. この山の高さは $\phi$ 正負で違っていて, $p_{1}$ と $p_{2}$ で はその高低が逆になっている，さらにての高低は， $p_{\mathbf{l}}$ で いえば $\theta_{N}$ が $30^{\circ}$ のときは左の山が勝つ（全場合数の 63 \%がそうなっている）のに対し， $\theta_{N}$ が $60^{\circ}$ しきは右の 山が勝っている $(85 \%)$. 乙れは $\theta_{N}$ が小さいときは $\phi=$ -1 付近の合格カードを不合格とし, 逆に $\theta_{N}$ が大きい 場合には $\phi=+1$ の付近の合格カードを不合格とする 傾向を示唆している，すなわち現状に対する無意識のフ ィードバック心理が働いているわけで，記憶されている 合格幅の小さいものは大きい方へ，大きいものは小さい 方へ修正しようとする心理作用の現れと理解できる.

図 5 は $\Delta \theta_{S} / \Delta \theta_{R}$ に対して $p_{A}$ をプロットしたもので あるが，いずれも右上りの曲線になっている．すなわち 提示スライドの範囲 $\Delta \theta_{R}$ に対し，合格幅 $\Delta \theta_{S}$ が広いほ ぞ，換言すれば検査が甘いほど第 1 種の誤り，すなわち 良品を不合格とする誤りが増す。さらに言いなおせば， 検査基準が甘いほど，その検査を厳しくしょうとするわ けで（合格が多くでることに不安を感じて），ててでも 前述のフィードバック作用が読みとれる.そしてそれは $C_{A} / C_{B}$ の值が 1 のとき，すなわち事前に主観がないと きほど強く現れている，さらに図 6 は全データを $\Delta \theta_{S} /$ $\Delta \theta_{R}$ 別に整理したものであるが，概略して 

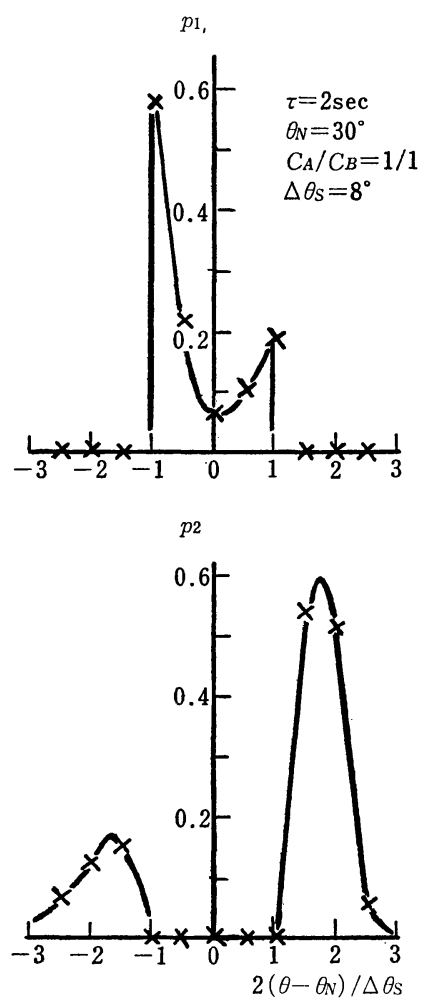

$p_{B} / p_{A}=5.0 \mathrm{e}^{-2.06 \Delta \theta S / \Delta \theta R}$

$\cdots \cdot(11)$

なる実験式にまとめうる.乙れは図 5 と同じ意味のてと を定量化したもので, 合格圈が広くなるほど検査を箃し

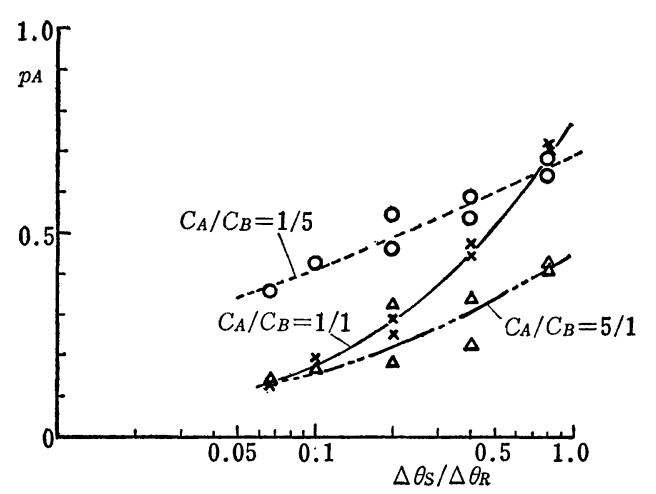

図 $5 C_{A} / C_{B}$ をパラメータとしたときの $\Delta \theta_{S} / \Delta \theta_{R}$ に対 する条件づき第 1 種の誤り $p_{A}$ の変化

Fig. 5 Relationship between error rate of Type 1 errors $p_{A}$ and relative allowance $\Delta \theta_{S} / \theta_{R}$ for three cases of varing $C_{A} / C_{B}$.
図 4（a） 無次元視標角度

$2\left(\theta-\theta_{N}\right) / \Delta \theta_{S}$ に対する第 1,2 種の誤り $p_{1}, p_{2}$ の 1 例 $\left(\theta_{N}=\right.$ $\left.30^{\circ}\right)$

Fig. 4(a) A tipicale xample of the distributions of Type 1,2 errors respectively with respect to the dimension less angle of $2\left(\theta-\theta_{N}\right) / \Delta \theta_{S},\left(\theta_{N}=30^{\circ}\right)$.

図 4(b) 無次元視標角度

$2\left(\theta-\theta_{N}\right) / \Delta \theta_{S}$ に対する第 1,2 種の誤り $p_{1}, p_{2}$ の 1 例 $(\theta N=$ $\left.60^{\circ}\right)$

Fig. 4(b) A tipical example of the distributions of Type 1, 2 errors respectively with respect to the dimensionless angle of $2\left(\theta-\theta_{N}\right) / \Delta \theta_{S}\left(\theta_{N}=60^{\circ}\right)$.

\section{くしている現れである.}

つぎに 2 節で述べたエントロピモデルを考える. $C_{A}$

と $C_{B}$ に具体的な数值をあてはめ，(7)，(8)式から $W_{0} お$

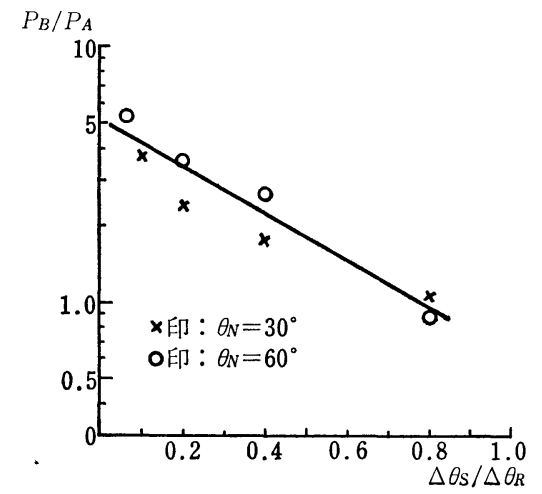

図 6 第 1,2 種の誤りの比 $p_{B} / p_{A}$ の $\Delta \theta_{S} / \Delta \theta_{R}$ による変 化

Fig. 6 Ratio of the two types of errors $p_{B} / p_{A}$ vs. $\Delta \theta_{S} / \Delta \theta_{R}$. 


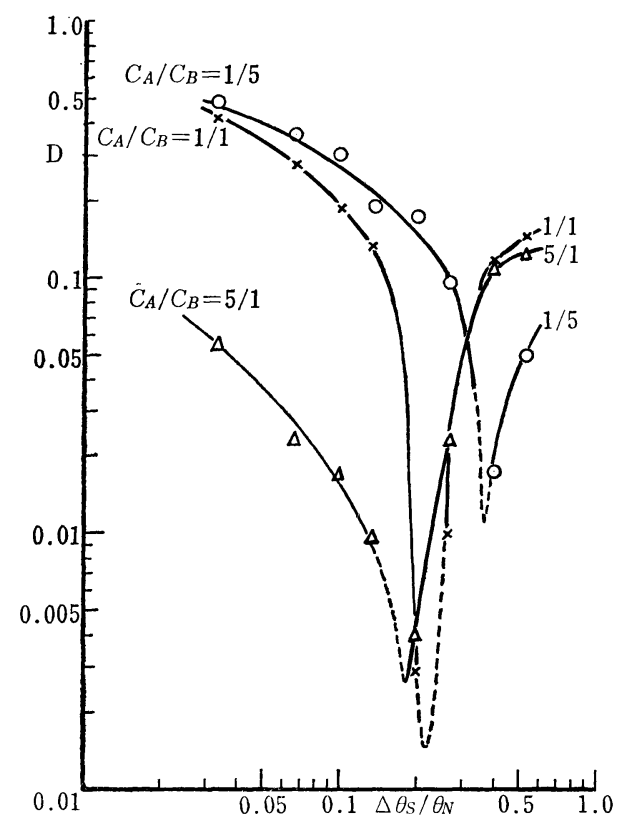

図 $7 C_{A} / C_{B}$ をパラメータとしたときのエントロピモ デルからのかい離度曲線

Fig. 7 Discrepancy from the entropy model in three cases of $C_{A} / C_{B}$.

よび $p_{A}^{*}, p_{B}{ }^{*}$ を算出すると下記のとおりである.

$\begin{array}{llll}C_{A} / C_{B} & 1 / 1 & 1 / 5 & 5 / 1 \\ W_{0} & 2.0 & 1.3247 & 1.3247 \\ p_{A} * & 0.5 & 0.755 & 0.245 \\ p_{B} * & 0.5 & 0.245 & 0.755\end{array}$

しかるに現丰には，3節で述べたように，lを最小にす るととにのみ着目した 1 因子エントロピモデルだけでは 律しえないそれ以外の多数の因子も判定のメカニズムに 参与しているであろう. そてで 1 因子モデルからのかい 離度 $D$ を(9)式を用いて計算し， $\Delta \theta_{S} / \theta_{N}$ に対してプロッ トしたものが図 7 である（図 5，6との対比を考えれ ば，横座標は $\Delta \theta_{S} / \Delta \theta_{R}$ とするのが好ましいが，データ が重なって見にくいので， $\Delta \theta_{S} / \theta_{N}$ を採用している). 図 はパラメータ $C_{A} / C_{B}$ でとにきわめてシャープな曲線が えられている.すなわち各 $C_{A} / C_{B}$ における極小点は, 1 因子モデルと最もよく一致する点を示し，それから遠 ざかるにつれ，てのモデルから急速に離れてゆく，そし て全体として $C_{A} / C_{B}$ の值が $5 / 1,1 / 1,1 / 5$ の順にDの 值が大きくなる．(10)式に示したように，Dはつねに非負 であり,また $D=0$ はデータとモデル值とが完全に一致
したときにのみ生じる.したがってDの値が小さいほど モデルとの一致のよさを示している，てのように，ある 特定の $\Delta \theta_{S} / \Delta \theta_{N}$ で $D$ が極小を示す理由はつぎのように 考えられる．すなわち極端に合格規準 $\left(\Delta \theta_{S} / \theta_{N}\right)$ が広か ったり狭かったりすれば，図 $5 ， 6$ で説明したような合 格規準の修正作用やその他各種の要因が働いて，単純な 1 因子モデルからずれてくる. それに対し $C_{A} / C_{B}$ 別に ある程度適当な合格規準のときは，多くの原因が消光て 純粋な 1 因子のみのモデルが形成されると思われる.

さて以上は，実際の測定值が 1 因子エントロピモデル でぞの程度まで整理できるかを示したものであった．図 7 はそれを視覚的にみせたものであり，仮定 1 と仮定 2 との兼效あいの結果が一番よく現実と一致している点を シャープに示したものである. それなら仮定 2 だけを取 り出して眺めたら，実験データはどのように整理される であろうか。それをみるためにエントロピ $H を \Delta \theta_{S} / \theta_{N}$ についてプロットしたのが図8である.

前にも述べたように，Hが最大となるのはすべての出 現確率が等しいときであるから， $p_{A}=p_{B}=1 / 2$ t(4)式に 代入して， $H=1.0$ ビットがあいまいさが最大のときの 值である. 図 8 をみれば, $C_{A} / C_{B}$ が $1 / 1$ のときは $\Delta \theta_{S} /$ $\theta_{N}$ が 0.25 の付近で $H_{\mathrm{Max}}$ の值は $0.99 \cong 1.0$ となってい るが，その他では $H$ は小さくなっている. $C_{A} / C_{B}$ が $1 / 5$ の場合は， $\Delta \theta_{S} / \theta_{N}$ が大きいとてろで $H$ は小さいが，そ れ以外では一般的に 1 に近い值をとっている。 てれに対 し $C_{A} / C_{B}$ が5/1 では， $\Delta \theta_{S} / \theta_{N}$ が大きいとてろで 1 に 近い以外は，ほとんど全域にわたって 3 者中一番小さい 值を示している.エントロピの減少は自然状態からのか

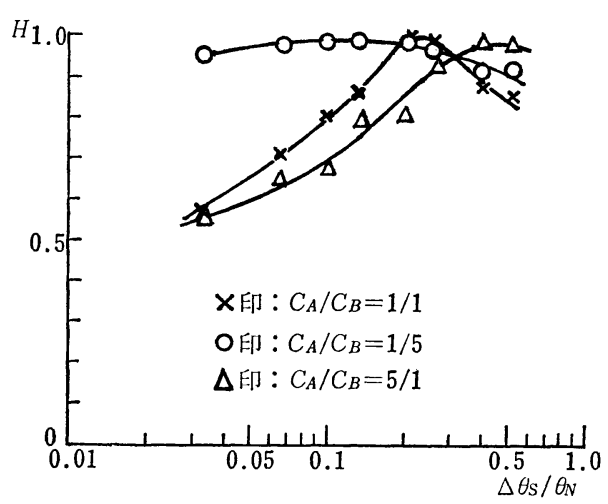

図 8 各 $C_{A} / C_{B}$ に扔けるエントロピHの $\Delta \theta_{S} / \theta_{N}$ に対 する変化の様子

Fig. 8 Distribution of entropy $H$ (bits) with respect to $\Delta \theta_{S} / \theta_{N}$ at three cases of $C_{A} / C_{B}$. 
い離を，すなわち何らかの意志が作用したてとを意味す るから， $C_{A} / C_{B}$ が5/10ときは $\Delta \theta_{S} / \theta_{N}$ がとくに大き い場合以外のほぼ全域で，何らかの意志が働いたとみる べきであるのに対し，クレームコスト高，すなわち $C_{A} /$ $C_{B}$ が $1 / 5$ のときは曲線はなめらかで 1.0 に近く，全般 的に中立的心理状態で査定したてとを示している. $C_{A} /$ $C_{B}=1 / 1$ のときは, 実験前の予想に反し中立から一番は ずれておりむしろ純粋な立場が維持できず何らかの心 理的外因が働いてどちらかに傾いた結果を示している.

\section{6. 結 論}

以上のように目視検查を例にとり，判断基準のゆれを エントロピを用いてある程度説明することができた。こ れを要約すると。

1）検査ミスに伴う損害を最小にしようとする 1 因子 モデルを当てはめ,

2）それからのかい離度 $D$ を測定した。

3） $D$ は相対的合格幅 $\Delta \theta_{S} / \theta_{N}$ に対して，シャープな 極小值をもっている（図 7 )。

4）製造コスト $\left(C_{A}\right)$ が高い方が，クレームコスト $\left(C_{B}\right)$ 高のときより 1 因子モデルに近い（図 7$)$.とれ は $C_{A}$ は直接的で理解しやすいのに対し， $C_{B}$ は間接的 で值感的でないためと考えられる.

5）同じ判定（合格あるいは不合格）が多く続くと不 安になり，記憶された判断基準を修正しようとする反作
用が生じ，かえって誤りが増える（図 5 )。

6）エントロピHの変化からみて, $C_{A} / C_{B}$ が1のと きがもっとも中立的でない（図 8).

以上の実験では，検査ミスによる損失 $l$ を罰金として 被験者に課すことはしなかったが，これを行えば実験結 果はさらに明瞭に現れると想像される.

おわりに長期間にわたり実験に従事した関西大学工学 部学生（当時）の大西，大羽，大橋の 3 君および被験者 になっていただいた諸君に深く感謝いたします。

\section{考文献}

1）野呂影勇：検査計測の研究法, 人間工学, $15(6)$, $289,1979$.

2）志村正道：パターン認識と学習機械，66，248, 昭 晃堂.

3）小野 茂：心理学における数学的方法, 53〜 54, 培風館.

4） 国沢 清：エントロピ・モデル，19，110，日科 技連.

5）西田俊夫：ファジィ集合とその応用，132,森北出 版.

6) C.H. Coombs : Mathematical Psychology, Prentice-Hall, 1970.

7) T.O. Kvalseth : A Decision Theoretic Model of the Sampling Behavior of the Human Process Monitor, Human factors, 21(6).

\section{HFS '81 25 th 年次大会報告*}

\section{岡田良知**}

1981年10月12日から16日まで，ロ チェスター・ニューヨークのジェネ シープラザ・ホリデイインにおいて アメリカ合衆国人間工学会 (HFS : Human Factors Society) の第25回 年次大会が開催された。

* 昭和 57 年 1 月 18 日受付

** 産業医科大学 Occupational and Environmental Health School of Medicine.

$$
\text { ロチェスター・ニューヨークと }
$$
は, 五大湖の一つオンタリオ湖に臨 む人口 30 万の都市であり，ニューヨ 一ク州西部に位置する有数の工業都 市でもある. 周囲は森林に囲まれ， 西方エリ一湖との接合部にはナイア ガラの大滝もある景勝の地である. 時も秋の深まりが押し寄せており， 空から訪れたロチェスターの街は周 囲が一面赤・黄・緑のまだらにいり
まじった美しい䋐秋でうずめられて いた。

HFS '81 大会は参加国十余に及 び，その内訳は，アメリカ 180 件, 英国 7 件をはじめとして, カナダ, フランス, イスラェル, スイス, イ タリア, フィンランド, ドイツ, オ ランダなどにまたがり, 特にヨーロ ッパからの参加が目立った．地理的 にも東海岸で行う大会では, 大西洋 